\title{
ATTITUDES TOWARD VULNERABLE POPULATIONS IN THE TIME OF COVID-19: CRITICAL DISCOURSE ANALYSIS OF GAZETA.PL ONLINE COMMENT SECTIONS
}

\author{
MICHALINA GRZELKA ${ }^{1}$
}

${ }^{1}$ State University of New York at Albany, Department of Anthropology, 1400 Washington Ave, Albany, NY 12222, United States. ORCID: 0000-0003-3753-8632, Email: mgrzelka@albany.edu

ABSTRACT: According to the World Health Organization, older people and people with preexisting medical conditions appear to be more vulnerable to becoming severely ill with the COVID-19 virus (World Health Organization 2020). A few journalists (Arielle 2020, Held 2020) have pointed out that in light of the current COVID-19 crisis, vulnerable populations such as elderly people, people with disabilities, and people with preexisting medical conditions have been talked about as if they were "disposable" or "expendable". Therefore, this study will attempt to examine how vulnerable populations are perceived by Polish public in the context of the global COVID-19 pandemy. In order to achieve that, I will analyze, by the means of critical discourse analysis, comment sections below online articles and editorials covering the topic of the COVID-19 virus on the popular Polish portal Gazeta.pl. In order to narrow down the scope of this study I will only focus on those articles and comments that were published in the week following March 4th 2020 when the first COVID-19 case in Poland was officially confirmed. I believe that this preliminary study will provide useful data for assessing public attitudes toward vulnerable people in times of crisis.

KEYWORDS: COVID-19, critical discourse analysis, elderly people, media, people with disabilities 


\section{INTRODUCTION}

According to the World Health Organization (2020), older people and people with preexisting medical conditions appear to be more vulnerable to becoming severely ill with the COVID-19 virus. As a result, many people are concerned about their elderly or ill relatives and loved ones who have the highest risk of getting seriously ill from the virus (Stieg 2020). However, that is not always the case. A few journalists (eg. Arielle 2020, Held 2020) have reported that in light of the current COVID-19 crisis, vulnerable populations such as elderly people, people with disabilities, and people with preexisting medical conditions have often been talked about as if they were "disposable" or "expendable". Other authors (eg. Merrick 2020) have warned that due to the shortage of medical equipment, medical professionals will soon face such difficult moral dilemmas as deciding which COVID-19 affected patients should go on ventilators. Despite the fact that the position of vulnerable populations in the midst of the COVID-19 crisis as well as ethical issues surrounding their access to medical treatment are being widely discussed in international media, the topic at hand is almost completely absent from the mainstream debate on COVID-19 in Poland. Despite that, I believe it is crucial to learn more about how vulnerable populations are perceived by Polish public in the context of the global COVID-19 pandemy. In order to achieve that, I will examine, by the means of critical discourse analysis, comment sections below online articles and editorials covering the topic of the COVID-19 virus on the popular Polish portal Gazeta.pl. To narrow down the scope of this study, I will only focus on those articles and comments that were published in the week following March 4th 2020 when the first COVID-19 case in Poland was officially confirmed. As a result of this analysis, this paper will attempt to answer the following questions: How are vulnerable populations "talked about" by the Gazeta.pl readers in the context of the COVID-19 crisis? Are the Gazeta.pl readers aware of the level of risk the COVID-19 virus poses to such vulnerable groups as elderly people, people with disabilities, and people with preexisting medical conditions? Do they express any concern for those people who are at the highest risk of getting seriously ill with the COVID-19 virus? Are they worried about the well-being of their elderly or ill relatives and loved ones? I believe that my attempt to answer these and other related questions will provide useful preliminary data for further studies of attitudes toward vulnerable people in times of crisis.

\section{LITERATURE REVIEW}

Elderly people, people with preexisting medical conditions and people with disabilities are more vulnerable to becoming seriously ill with the COVID-19 virus (Ryan 2020). In the context of the global pandemic and the perceived vulnerability of some groups of people to the virus and its repercussions for their treatment, it has to be underlined that people with disabilities are often labeled "the Other" since they are considered somewhat separate from people who identify as non-disabled (Reid-Cunningham 2009). However, what makes the "otherness" of disability unique, is the fact that anyone may become disabled at some point of their life and cross the border between what is perceived as different and what constitutes "normal". The border between the 
"normal" and the "pathological", moreover, is very fluid and depends on reactions to physical and behavioral differences that vary between cultures and communities (Reid-Cunningham 2009).

Anthropologists studying disability have paid close attention to the ways in which personhood and/or social adulthood is attributed to or withheld from people with disabilities. For example, in her study on disability and personhood in Central Borneo, Nicolaisen (1995) argues that in order to better understand how personhood is conceptualized and described across cultures, the classic definition of personhood as defined and described in terms of social properties has to be expanded and focus on "the cultural perception of the biological constitution of the human being itself" (3940). For instance, among the Punam Bah studied by Nicolaisen (1995), an individual can only achieve full personhood through marriage and producing offspring. This has profound consequences for people with disabilities, who are deemed unmarriageable by local people (Nicolaisen 1995). As a result, adult people with disabilities are forever caught in the liminal stage between a child and an adult, and a less-than-full person since full personhood can only be granted to those who get married and have children (Nicolaisen 1995). Other researchers argue that people with disabilities often tend to be "infantilized and devalued" (Gammeltoft 2014:184) by non-disabled people. As a general rule, non-disabled people frequently fail to recognize people with disabilities as "full" persons (Gammeltoft 2014; Landsman 2009). For example, according to some researchers, Vietnamese mothers of children with disabilities often feel unable to offer their children a fully human life, while expectant mothers who anticipate the birth of a disabled baby believe that their child would never grow up to be complete (Gammeltoft 2014). In American culture the personhood of people with disabilities is often questioned and diminished. According to Landsman (2009), "such individuals have been viewed not only as incapable of giving, but as relying upon the gifts of others" (p. 146), a perception which echoes the attitudes toward people with disabilities in Vietnam as described by Gammeltoft (2014).

Anthropologists studying disability have documented how denying people with disabilities the status of a "full" person can also lead to a denial of one's humanity such that it becomes acceptable to end their life. For instance, in some societies children whose bodies looked different were sometimes neglected or killed (Gammeltoft 2014). Other cultures, however, prohibited the elimination of the weakest infants, even though they still considered babies with disabilities as "different". For example, the Chagga of East Africa believed that even babies with disabilities were created by God and since they were deemed as sent by spirits, they were granted a sacred existence (James 2000), although such practice would suggest that people with disabilities were not considered to be humans either. Dehumanization of people with disabilities has profound consequences for their level of access to medical treatment as well. David Abbott, a researcher who works with boys and men who have Duchenne muscular dystrophy, discusses how "the availability of health resources often devalues short lives, with Duchenne patients even deemed to be 'futureless persons'” (Johnstone 2020:n.p.). Other studies report that people with intellectual disabilities frequently experience mistreatment at the hands of hospital staff (Perry 2018). Stramondo (2020) 
argues that such attitudes toward people with disabilities stem from "deeply biased quality of life judgment" (n.p.). He also points out that such judgments are often made by people, including medical professionals, who have never experienced disability, be it a physical or intellectual one, themselves (Stramondo 2020).

Elderly people often experience similar attitudes in their encounters with health professionals. For example, Minichiello, Browne and Kendig (2000) argue that medical professionals constitute a significant source of ageist treatment. Furthermore, Nelson (2005) reports that "doctors all too often think that because old age is unstoppable, illnesses that accompany old age are not that important, because such illnesses are seen as a natural part of the aging process” (p. 211). Nussbaum et al. (2005) observe that general internists and family physicians are often unwilling to provide primary care services to elderly patients. Moreover, some studies suggest that "physicians find older patients difficult to treat and would rather focus on younger, healthier patients" (Nussbaum et al. 2005:295).

Such ableist and ageist attitudes can be particularly detrimental to the health of elderly people, people with disabilities, and people with chronic illnesses in times of global health crisis such as the COVID-19 pandemic. A quick review of press articles covering the topic of the COVID-19 virus brought to the surface some unsettling news concerned with vulnerable populations in the midst of the crisis. In Spain soldiers drafted to disinfect residential homes have found elderly people "abandoned and dead in their beds" (Jones 2020:n.p.). In the United Kingdom Butler and Walker (2020) warn that the coronavirus emergency measures will put people with disabilities and elderly persons at risk. The Guardian columnist Frances Ryan (2020) points out that "phrases such as 'only the long-term sick are dying' come across as somewhat flippant about - or even accepting of - the risk to millions of people with heart problems, asthma or diabetes" (n.p.). Echoing these concerns, the Royal Commission into Violence, Abuse, Neglect and Exploitation of People with Disability in Australia issued "Statement of Concern" in relation to the global COVID-19 pandemic and possible measures that will be undertaken in order to tackle this crisis. The Statement (Royal Commission 2020) acknowledges that many people with disabilities are anxious about the COVID-19 pandemic and feeling that "they are being left behind or ignored in government and community responses" (p.1). In the United States disability rights organizations warn that in Washington and Alabama, in accordance with local disaster preparedness plans, people with intellectual disabilities are "a lower priority for lifesaving treatment” (Silverman 2020:n.p.). In Texas lieutenant governor Dan Patrick told Fox News that he believes that many elderly people in the United States would be willing to die from COVID-19 in order to avoid shutting down the entire country and to save the economy for younger generations (Beckett 2020).

Those news highlight the vulnerability of people with disabilities, elderly people, and people with chronic illnesses in light of the global COVID-19 pandemic. In many cases, they are treated by the public like second-class citizens, while their lives are considered expendable, disposable, and "futureless". As already mentioned above, the ethical discussions surrounding vulnerable populations' access to medical treatment in times of possible equipment and staff shortages are largely absent from the Pol- 
ish public debate on COVID-19. There exist, however, a few reports suggesting that vulnerable people in Poland are not only more likely to become severely ill with the COVID-19 virus but are also at a higher risk of becoming neglected, abandoned or forgotten in the midst of the current public health crisis. For instance, it was recently revealed that 52 residents (and 8 members of staff) of a nursing home for people with intellectual disabilities in Niedabyl near Radom had contracted the COVID-19 virus (Klauziński 2020). Experts and social workers warn that residents of nursing homes are at a greater risk of contracting the virus, not only because many of them are elderly, have disabilities or preexisting medical conditions, but also because nursing homes employees are not properly equipped with masks and other personal protective equipment (Klauziński 2020). In light of the above, it is crucial to examine how Polish society "talks about" its most vulnerable members in the context of the COVID-19 crisis.

\section{METHODOLOGY}

For the purpose of this study I analyzed comments that were posted under 7 online articles concerned with COVID-19 that appeared in the news section of the popular Polish portal Gazeta.pl between March 4th and March 10th 2020. Due to time constraints I chose to analyze only those articles and comments that were published in the week following March 4th 2020 when the first COVID-19 case in Poland was officially confirmed. In order to collect the most relevant articles I used Google Advanced Search. On March 25th I typed in the This OR That window "koronawirus OR COVID-19" search phrase. To be more specific, I also selected the "page title" option in order to make sure that my search words appear in titles. Next, I selected "Polish" as my search language. Furthermore, by typing "https://wiadomosci.gazeta.pl” I specified that I was only interested in those articles that appeared in the news section of the Gazeta.pl portal. After I obtained the initial results I narrowed down the search date from March 4th 2020 to March 10th 2020. Ultimately, I obtained 78 results. However, one of the links was inactive and therefore I had to work with 77 results. Out of them, 47 links led me to articles concerned with COVID-19 in Poland, while the remaining 30 - to international news on COVID-19. In order to make my data set more manageable (the average number of comments was about 88 for articles on COVID-19 in Poland and about 6 for international news), I decided to analyse only those comments that were posted under an article with the highest number of comments on a given day. As a result of my selection, I obtained the following data set:

March 4, 2020: "Prymas reaguje na słowa księdza o tym, że koronawirus to kara za homoseksualizm. 'Dziwna teologia'” [Primate reacts to the words of the priest who said that coronavirus is a punishment for homosexuality. 'Weird theology'] - 438 comments

March 5, 2020: "Dr Grzesiowski: Jeżeli koronawirus dotrze do małych miejscowości, to zachorują tam wszyscy” [Dr. Grzesiowski: If coronavirus reaches small towns and villages, everyone there will get sick] - 341 comments 
March 6, 2020: “Koronawirus w Polsce. Żołnierze i wojskowi lekarze są w stanie gotowości" [Coronavirus in Poland. Soldiers and army doctors are in full readiness] - 48 comments

March 7, 2020: “WOŚP przenosi ogłoszenie wyniku 28. finału ze Szczecina do Warszawy. Powodem koronawirus” [The Great Orchestra of Christmas Charity moves the announcement of the 28th final results from Szczecin to Warsaw. Reason? Coronavirus] - 56 comments

March 8, 2020: "Koronawirus. Nowe fakty ws. pacjenta z Raciborza. Przyjechał z Włoch ponad tydzień temu" [Coronavirus. New facts regarding the patient from Racibórz. He returned from Italy over a week ago] - 196 comments

March 9, 2020: “'Wzywam Bielana, by nie siał paniki'. Grodzki publikuje wyniki badań na obecność koronawirusa” ['I urge Bielan to stop spreading panic'. Grodzki publishes the results of his coronavirus test] - 400 comments

March 10, 2020: "Koronawirus w Polsce. Abp Gądecki apeluje do parafii o zwiększenie liczby mszy” [Coronavirus in Poland. Archbishop Gądecki appeals to parishes to increase the number of masses] - 973 comments.

In total, I read and analyzed 2,452 online comments for the purpose of this study. It is worth mentioning that all the articles in the data set presented above are concerned with the COVID-19 situation in Poland. In general, the articles covering the COVID-19 crisis worldwide were not as widely commented as the ones concerned with Poland only. I analyzed the articles available in the data set using critical discourse analysis. Since critical discourse analysis (CDA), as a tool for studying the role of discourse in society, "focuses on (group) relations of power, dominance and inequality and the ways these are reproduced or resisted by social group members through text and talk" (van Dijk 1995:18), I decided it is best equipped for studying how vulnerable populations (or, in other words, those who have "less" power under certain circumstances such as the COVID-19 pandemic, among others) are "talked about" in times of crisis.

\section{ANALYSIS}

Out of 2,452 online comments analyzed for this study, 57 referred to the situation of vulnerable populations (elderly people, people with disabilities, people with preexisting medical conditions) during the COVID-19 crisis. 1 comment appeared under the March 4th article, 4 comments - under the March 5th article, 0 comments under both the March 6th and March 7th articles, 6 comments under the March 8th article, and 1 comment under the March 9th article. The highest number (46) of relevant comments appeared under the article "Koronawirus w Polsce. Abp Gądecki apeluje do parafii o zwiększenie liczby mszy" [Coronavirus in Poland. Archbishop Gądecki appeals to parishes to increase the number of masses] published on March 10th.

Out of those 57 comments, only 1 referred to people with preexisting medical conditions only. 0 comments mentioned people with disabilities only. The vast majority of 
the comments - 56 - referred to elderly people as those who are particularly vulnerable to becoming seriously ill from the COVID-19 virus.

In general, the authors of the analyzed comments are aware of the fact that elderly people and people with preexisting medical conditions are especially vulnerable during the COVID-19 pandemic. For instance, a user named marykownow (2020) points out:

“Wszyscy ci w sile wieku, którzy jeżdżą teraz za granicę, muszą wiedzieć, że pewnie przeżyją, ale w praktyce zabiją swoich rodziców.” (sic) [All those young people who are currently traveling abroad should know that they themselves will probably survive (the COVID-19 virus) but they will practically kill their parents.]

Only one comment echoes the concern expressed by Frances Ryan (2020), who observed that the language used by mass media and experts to describe those who are most vulnerable to getting severly ill with COVID-19 makes it sound like their lives are not important or worth saving:

“Może zarówno media jak i eksperci przemyśleli by to co mówią - radosne pocieszanie, że ciężko chorują jedynie starsi ludzie obarczeni chorobami to potworność! (...)" (sic) [Maybe both media and experts should change the way they talk (about vulnerable people), (instead of) merrily comfort people (by saying) that only elderly persons with preexisting conditions get seriously ill (with COVID-19), because that (sounds) horrible!] (azalka12 2020)

Some readers express their concern for elderly people in their comments referring to the COVID-19 pandemic and related events:

“(...) Ja mam starą matkę która cieszy się życiem,i chciałbym by to jeszcze potrwało (...)” (sic) [I have an elderly mother who enjoys life and I would like [her to enjoy it] a little bit longer.] (desnoran3 2020)

“Zamiast zalecić starszym ludziom aby słuchali transmisji mszy w radiu lub telewizji oni zwiększają liczbę mszy w kościołach , matoły.” (sic) [Instead of telling the elderly to listen to a mass broadcast on radio or television they (priests) increase the number of masses in churches, idiots.] (rozterka47 2020)

The highest number of comments appeared under the article reporting on archbishop Gądecki who had requested that parishes increase the number of masses in order to decrease the number of churchgoers attending each mass and therefore to minimize the risk of COVID-19 infection (jagor 2020). A number of readers took it to the comment section in order to express their anger at the archbishop, priests, and Catholic Church in general as well as to castigate the archbishop for his perceived recklessness and greed. In addition, some readers suggest that churches should be closed in order to decrease the risk of COVID-19 infection among the elderly churchgoers:

“Raczej powinno się zamknąć kościoły na 21 dni. Ponieważ najczęściej ludzie w podeszłym wieku tam chodzą a Oni są najbardziej narażeni na powikłanie po chorobowe." (sic) [(They) should rather shut down churches for 21 days. Because 
it is usually elderly people who go there and they are at the highest risk of (postCOVID-19) complications.] (lolek1 2020)

"Zamknąć te siedliska zarazy w trybie natychmiastowym !!! Tym bardziej, że głównym targetem tej "firmy” są ludzie starsi, czyli najbardziej podatni." (sic) [Let's immediately close all those nests of pestilence! Especially since the main target of that "company" are elderly people who are the most vulnerable ones.] (Zygfryd Mamut 2020)

“GŁUPOTA SUKIENKOWYCH SIĘGNĘŁA ZENITU!!!!!!!!!!!!ZAMIAST ODWOŁAĆ, TO NARAŻAJĄ, SZCZEGÓLNIE EMERYTÓW NA NIEBEZPIECZEŃSTWO!!!!!!!!!!!!!!!!!!” (sic) [The stupidity of priests has reached its heights! Instead of cancelling (masses), they endanger (people), especially pensioners.] (andrew-live 2020)

Other readers, however, express their satisfaction with the prospect of putting the elderly churchgoers at a higher risk of contracting the COVID-19 virus. Some of them refer to elderly people, especially those who frequent churches, by such derogatory terms used in reference to older people as "mohery" (a derogatory term meaning older ladies who are avid churchgoers) or "staruchy" (old geezers). Other suggest that those elderly pensioners who still go to church despite the warnings, will at least save the Social Insurance Institution (ZUS) some money, when they contract the COVID-19 virus and die:

“Społeczeństwo się odmłodzi, zlaicyzuje, ZUS zaoszczędzi. Same plusy.” [Society will get younger, less religious, ZUS will save (some money). We will only gain.] (kalim13 2020)

"Przyoszczędzi się na emeryturach, w ZUS-ie strzelają szampany.” (sic) [We will save on pensions. They are opening champagne at ZUS.] (qurczak 2020)

“Jeszcze procesje z kadzidlami niech robia! Wszystkie mochery do piachu. Ale siem oblowia." (sic) [(Let them have) processions with incenses! All "mohery" can go and die. They (priests) will get rich.] (zwierzoczlekoupior 2020)

Furthermore, some readers use the fact that older persons and people with preexisting medical conditions are more likely to become severely ill with the COVID-19 virus to get back at certain public figures, for instance Małgorzata Kidawa-Błońska (a presidential candidate who is sixty years old) or Rafał Ziemkiewicz (a journalist):

“Pan Ziemkiewicz ma cukrzycę. To niestety źle rokuje przy koronawirusie.” [Mr Ziemkiewicz has diabetes. This is bad news when it comes to coronavirus.] (martha.wise 2020)

"A nie niepokoi ciebie Kichawa Końska wałęsające się po jarmarkach? W końcu w grupie ryzyka.” (sic) [Aren’t you worried that (Kidawa-Błońska - the Polish version contains an untranslatable and insulting word game based on her last name) still tours the fairs? I mean, she's in a risk group.] (soso_soso 2020) 


\section{CONCLUSION}

This preliminary study indicates that a significant number of Gazeta.pl readers are aware of the fact that elderly people are especially vulnerable to getting seriously ill with the COVID-19 virus. In addition, some readers mention preexisting conditions such as diabetes as a risk factor in becoming ill with the COVID-19 virus. However, none of the comments analyzed in this paper mentions people with disabilities as those who are particularly vulnerable in the midst of the COVID-19 crisis. Some readers express their worry over elderly people but others mock them and talk about them as if they were expendable, which is particularly alarming in times of crisis. Unfortunately, due to time constraints I was not able to compare the Gazeta.pl comments with comments on COVID-19 that appeared on Wirtualna Polska as I initially planned. Moreover, since the data set analyzed in this paper is not very significant the results of this analysis are not by any means reflective of attitudes toward vulnerable populations in Poland and therefore should not be generalized. I believe, however, that this preliminary study offers some interesting data that could be used for further studies of such attitudes in Poland.

FUNDING: This research received no external funding.

CONFLICT OF INTEREST: The author(s) declare(s) no conflict of interest.

\section{REFERENCES}

andrew-live. 2020. Re: Koronawirus w Polsce. Abp Gądecki apeluje do parafii o zwiększenie liczby mszy [Comment]. March 10. Retrieved March 26, 2020 (https://wiadomosci.gazeta.pl/wiadomosci/7,114883,25776294,koronawirus-w-polsce-abpgadecki-apeluje-do-parafii-o-zwiekszenie.html).

azalka12. 2020. Re: Dr Grzesiowski: Jeżeli koronawirus dotrze do małych miejscowości, to zachorują tam wszyscy [Comment]. March 5. Retrieved March 26, 2020 (https://wiadomosci.gazeta.pl/wiadomosci/7,114883,25760318,dr-grzesiowski-jezeli-koronawirus-dotrze-do-malych-miejscowosci.html)

Arielle, Zipporah. 2020. “Please Stop Treating Me Like I'm Disposable When You Talk About the Coronavirus.” HuffPost, March 13. Retrieved March 23, 2020 (https:// tinyurl.com/rn6w7s3).

Beckett, Lois. 2020. “Older People Would Rather Die Than Let COVID-19 Harm US Economy - Texas Official.” The Guardian, March 24. Retrieved March 30, 2020 (https://www.theguardian.com/world/2020/mar/24/older-people-would-rather-die-than-let-covid-19-lockdown-harm-us-economy-texas-official-dan-patrick).

Butler, Patrick and Peter Walker. 2020. “UK's Emergency Coronavirus Bill 'Will 
Put Vulnerable at Risk'.” The Guardian, March 23. Retrieved March 30, 2020 (https://www.theguardian.com/society/2020/mar/23/uks-emergency-coronavirus-bill-will-put-vulnerable-at-risk).

desnoran3. 2020. Re: Dr Grzesiowski: Jeżeli koronawirus dotrze do małych miejscowości, to zachorują tam wszyscy [Comment]. March 5. Retrieved March 26, 2020 (https://wiadomosci.gazeta.pl/wiadomosci/7,114883,25760318,dr-grzesiowski-jezeli-koronawirus-dotrze-do-malych-miejscowosci.html).

Gammeltoft, Tine M. 2014. Haunting Images. A Cultural Account of Selective Reproduction in Vietnam. Berkeley, CA: University of California Press.

Held, Shai. 2020. “The Staggering, Heartless Cruelty Toward the Elderly.” The Atlantic, March 12. Retrieved March 23, 2020 (https://tinyurl.com/tzrcofy).

jagor. 2020. “Koronawirus w Polsce. Abp Gądecki apeluje do parafii o zwiększenie liczby mszy" [Coronavirus in Poland. Archbishop Gądecki appeals to parishes to increase the number of masses]. Gazeta.pl, March 10. Retrieved March 26, 2020 (https://wiadomosci.gazeta.pl/wiadomosci/7,114883,25776294,koronawirus-wpolsce-abp-gadecki-apeluje-do-parafii-o-zwiekszenie.html).

James, Wendy R. 2000. "Placing the Unborn: On the Social Recognition of New Life." Anthropology \& Medicine 7 (2):169-189.

Johnstone, Fiona. 2020. "Chronicity and Crisis." The Polyphony, March 6. Retrieved March 30, 2020 (https://thepolyphony.org/2020/03/06/chronicity-and-crisis/).

Jones, Sam. 2020. “Spanish Minister Says Older People Found 'Dead and Abandoned'.” The Guardian, March 23. Retrieved March 30, 2020 (https://www.theguardian. com/world/2020/mar/23/spain-distributes-650000-testing-kits-as-coronavirusdeaths-rise-steeply).

kalim13. 2020. Re: Koronawirus w Polsce. Abp Gądecki apeluje do parafii o zwiększenie liczby mszy [Comment]. March 10. Retrieved March 26, 2020 (https://wiadomosci.gazeta.pl/wiadomosci/7,114883,25776294,koronawirus-w-polsce-abpgadecki-apeluje-do-parafii-o-zwiekszenie.html).

Klauziński, Sebastian. 2020. “Uderzyło w najsłabszych. Sześćdziesiąt osób z DPS w Niedabylu zakażonych koronawirusem" [It hit the most vulnerable ones. Sixty people from a nursing home in Niedabyl have contracted the coronavirus]. OKO. press, March 27. Retrieved March 30, 2020 (https://oko.press/uderzylo-w-najslabszych-szescdziesiat-osob-z-dps-w-niedabylu-zakazona-koronawirusem/).

Landsman, Gail Heidi. 2009. Reconstructing Motherhood and Disability in the Age of "Perfect" Babies. New York and London: Routledge.

lolek1. 2020. Re: Koronawirus w Polsce. Abp Gądecki apeluje do parafii o zwiększenie liczby mszy [Comment]. March 10. Retrieved March 26, 2020 (https://wiadomosci.gazeta.pl/wiadomosci/7,114883,25776294,koronawirus-w-polsce-abp-gadecki-apeluje-do-parafii-o-zwiekszenie.html).

martha.wise. 2020. Re: Koronawirus. Nowe fakty ws. pacjenta z Raciborza. Przyjechał z Włoch ponad tydzień temu [Comment]. March 8. Retrieved March 26, 2020 (https://wiadomosci.gazeta.pl/wiadomosci/7,114884,25769146,koronawirus-nowe-fakty-ws-pacjenta-z-raciborza-przyjechal.htm).

marykownow. 2020. Re: Koronawirus. Nowe fakty ws. pacjenta z Raciborza. Przy- 
jechał z Włoch ponad tydzień temu [Comment]. March 8. Retrieved March 26, 2020 (https://wiadomosci.gazeta.pl/wiadomosci/7,114884,25769146,koronawirus-nowe-fakty-ws-pacjenta-z-raciborza-przyjechal.htm).

Merrick, Rob. 2020. "Coronavirus: NHS Doctors to Be Given Guidelines to Decide Which Victims Go on Ventilators." Independent, March 20. Retrieved March 29, 2020 (https://www.independent.co.uk/news/uk/politics/coronavirus-boris-johnson-uk-doctor-victims-intensive-care-ventilator-italy-a9415356.html).

Minichiello, Victor, Jan Browne, and Hal Kendig. 2000. "Perceptions and Consequences of Ageism: Views of Older People.” Ageing and Society 20:253-278.

Nelson, Todd D. 2005. "Ageism: Prejudice Against Our Feared Future Self." Journal of Social Issues, 61 (2):207-221.

Nicolaisen, Ida. 1995. "Persons and Nonpersons: Disability and Personhood Among the Punan Bah of Central Borneo." Pp. 38-56 in Disability and Culture, edited by B. Ingstad and S. Reynolds Whyte. Berkeley, CA: University of California Press.

Nussbaum, Jon F., Margaret J. Pitts, Frances N. Huber, Janice L. Raup Krieger, and Jennifer E. Ohs. 2005. "Ageism and Ageist Language Across the Life Span: Intimate Relationships and Non-intimate Interactions.” Journal of Social Issues, 61 (2):287-305.

Perry, David M. 2018. "How Hospitals Mistreat Disabled Patients." Pacific Standard, June 29. Retrieved March 30, 2020 (https://psmag.com/social-justice/how-hospitals-mistreat-disabled-patients?fbclid=IwAR0HitnsyDz7nt6AjTnYEL2ADIfPwCQ5yukAabVmJ4_eMxSf-dQ2JOFshNc).

qurczak. 2020. Re: Koronawirus w Polsce. Abp Gądecki apeluje do parafii o zwiększenie liczby mszy [Comment]. March 10. Retrieved March 26, 2020 (https://wiadomosci.gazeta.pl/wiadomosci/7,114883,25776294,koronawirus-w-polsce-abpgadecki-apeluje-do-parafii-o-zwiekszenie.html).

Reid-Cunningham, Allison Ruby. 2009. „Anthropological Theories of Disability.” Journal of Human Behavior in the Social Environment 19:99-111.

Royal Commission. 2020. Statement of Concern: The Response to the COVID-19 Pandemic for People With Disability. Retrieved March 30, 2020 (https://disability.royalcommission.gov.au/system/files/2020-03/COVID-19\%20Statement\%20of\%20 concern.pdf).

rozterka47. 2020. Re: Koronawirus w Polsce. Abp Gądecki apeluje do parafii o zwiększenie liczby mszy [Comment]. March 10. Retrieved March 26, 2020 (https://wiadomosci.gazeta.pl/wiadomosci/7,114883,25776294,koronawirus-w-polsce-abpgadecki-apeluje-do-parafii-o-zwiekszenie.html).

Ryan, Frances. 2020. "Coronavirus Hits Ill and Disabled People Hardest, so Why Is Society Writing Us Off?” The Guardian, March 11. Retrieved March 30, 2020 (https:// www.theguardian.com/commentisfree/2020/mar/11/coronavirus-ill-disabled-people).

soso_soso. 2020. Re: Koronawirus. Nowe fakty ws. pacjenta z Raciborza. Przyjechał z Włoch ponad tydzień temu [Comment]. March 8. Retrieved March 26, 2020 (https://wiadomosci.gazeta.pl/wiadomosci/7,114884,25769146,koronawirus-nowe-fakty-ws-pacjenta-z-raciborza-przyjechal.htm). 
Silverman, Amy. 2020. “People With Intellectual Disabilities May Be Denied Lifesaving Care Under These Plans as Coronavirus Spreads.” ProPublica, March 27. Retrieved March 30, 2020 (https://www.propublica.org/article/people-with-intellectual-disabilities-may-be-denied-lifesaving-care-under-these-plans-as-coronavirus-spreads).

Stieg, Cory. 2020. "How to Talk With Your Older Parents About the COVID-19 Pandemic-and Have Them Actually Listen." CNBC, March 13. Retrieved March 30, 2020 (https:/www.cnbc.com/2020/03/13/how-to-talk-to-older-adults-who-arent-taking-coronavirus-seriously.html).

Stramondo, Joseph. 2020. "COVID-19 Triage and Disability: What NOT To Do." Bioethics.net, March 30. Retrieved March 31, 2020 (http://www.bioethics.net/2020/03/ covid-19-triage-and-disability-what-not-to-do/?fbclid=IwAR0PrP6c3GiWe5UKAH7TP1yGF6b88F3UzhVHpOoksFkds40RhaDXXHlxOtg).

van Dijk, Teun A. 1995. "Aims of Critical Discourse Analysis." Japanese Discourse 1:1727.

World Health Organization. 2020. “Coronavirus Disease (COVID-19) Advice For the Public.” Retrieved March 23, 2020 (https://www.who.int/emergencies/diseases/ novel-coronavirus-2019/advice-for-public).

zwierzoczlekoupior. 2020. Re: Koronawirus w Polsce. Abp Gądecki apeluje do parafii o zwiększenie liczby mszy [Comment]. March 10. Retrieved March 26, 2020 (https:// wiadomosci.gazeta.pl/wiadomosci/7,114883,25776294,koronawirus-w-polsceabp-gadecki-apeluje-do-parafii-o-zwiekszenie.html).

Zygfryd Mamut. 2020. Re: Koronawirus w Polsce. Abp Gądecki apeluje do parafii o zwiększenie liczby mszy [Comment]. March 10. Retrieved March 26, 2020 (https:// wiadomosci.gazeta.pl/wiadomosci/7,114883,25776294,koronawirus-w-polsceabp-gadecki-apeluje-do-parafii-o-zwiekszenie.html).

\section{BIOGRAPHICAL NOTE}

Michalina Grzelka is an anthropologist. She is a doctoral candidate at State University of New York at Albany in the United States, Department of Anthropology.

OPEN ACCESS: This article is distributed under the terms of the Creative Commons Attribution Non-commercial License (CC BY-NC 4.0) which permits any non-commercial use, and reproduction in any medium, provided the original author(s) and source are credited. 